\title{
Floodplain hydrology in an Amazon floodplain lake (Lago Grande de Curuaí)
}

\author{
M.P. Bonnet ${ }^{a, *}$, G. Barroux ${ }^{a}$, J.M. Martinez ${ }^{a}$, F. Seyler ${ }^{a}$, \\ P. Moreira-Turcq ${ }^{b}$, G. Cochonneau ${ }^{c}$, J.M. Melack ${ }^{d}$, G. Boaventura $^{e}$, \\ L. Maurice-Bourgoin ${ }^{a}$, J.G. León ${ }^{a}$, E. Roux ${ }^{a}$, S. Calmant ${ }^{f}$, P. Kosuth ${ }^{g}$, \\ J.L. Guyot ${ }^{\text {h }}$, P. Seyler ${ }^{\text {a }}$
}

a IRD - Institut de Recherche pour le Développement, UR154 LMTG, 14, Av. Edouard Belin, 31400 Toulouse, France

b IRD - Institut de Recherche pour le Developpement, UR154 LMTG - Departamento de Geoquímica, Universidade Federal Fluminense, Morro do Valonguinho s/ $n^{\circ}$ 24020-007 Niterói, RJ, Brazil

c IRD - Institut de Recherche pour le Développement, UR154 LMTG, Maison de la télédétection 34000 Montpellier, France

${ }^{\mathrm{d}}$ Bren School of Environmental Science and Management, University of California, Santa Barbara, CA, USA

e UNB - University of Brasilia, Instituto de Geociéncias, Universidade de Brasilia, Campus Universitario Darcy Ribeiro, ICCCentral CEP 70910-900 Brasilia, Brazil

f IRD - Institut de Recherche pour le Développement, LEGOS, 14, Av. Edouard Belin, 31400 Toulouse, France

s UMR TETIS (Cemagref-ENGREF-Cirad) - Territoires, Environnement, télédétection et Information Spatiale - Maison de la télédétection, 34000 Montpellier, France

h IRD - Institut de Recherche pour le Développement, UR154 LMTG, Universidad Nacional Agraria La Molina, Lima, Peru

Received 6 September 2006; received in revised form 12 October 2007; accepted 16 October 2007

KEYWORDS

Amazon river;

Floodplain;

River-floodplain

interactions;

Hydrologic residence

time

\begin{abstract}
Summary The floodplains of the Amazon basin influence the hydrology and fluxes of suspended solids and solutes on multiple scales. Our study focused on the floodplain of Lago Grande de Curuaí (Óbidos, Brazil), a $4000 \mathrm{~km}^{2}$ segment of floodplain and local upland catchment representative of the lower Amazon. Based on in situ and satellite data acquired from 1997 to 2003, we calculated the exchanges of water between the floodplain and the river and determined the temporal dynamics of flooded area water derived from river flooding, rainfall, runoff, and exchange with groundwater annually for six years. The Amazon River dominated the inputs of water to the flooded area year-round, accounting about $77 \%$ of the annual total inputs; rainfall and runoff accounted for about $9 \%$ and $10 \%$, respectively, while seepage from the groundwater system accounted for $4 \%$. The hydrologic residence time of the lake was about three months, and the floodplain made a net contribution of water to the river. The exported volume (net balance between water input and
\end{abstract}

\footnotetext{
* Corresponding author. Tel.: +33 5613326 61; fax: +33 561332560 .

E-mail address: bonnet@lmtg.obs-mip.fr (M.P. Bonnet).
} 
losses) varied between 4.2 and $7.3 \mathrm{~km}^{3}$ depending on the year and represented about 0.75 times the maximal storage reached each year.

(c) 2007 Elsevier B.V. All rights reserved.

\section{Introduction}

Extensive floodplains are associated with the Amazon River and its tributaries and these floodplains alter the transport of water and dissolved and particulate materials from upland watersheds through river systems to the sea (Dunne et al., 1998; Guyot et al., 2005; Hamilton et al., 2002; Hess et al., 2003; Junk, 1997; Meade et al., 1985; Melack and Forsberg, 2001; Seyler and Boaventura, 2001, 2003; Sippel et al., 1998). During residence of water on floodplains, substantial biogeochemical modifications occur under the influence of sorption and redox reactions and biotic processes (Melack et al., 2004; Richey et al., 1988, 1990; Seyler and Boaventura, 2001, 2003). These processes are influenced by the spatial and temporal patterns of hydrology, which are altered by the topography, soils and vegetation in the floodplain (Mertes et al., 1995). Hence, large spatial heterogeneities are expected and additional in situ data are required to reduce the uncertainties on regional and global estimates as mentioned in Melack et al. (2004).

Few attempts have been made to quantify floodplain and river interactions in the Amazon basin, in part because of the difficulties in acquiring data. Direct measurements or calculations of all the terms in the water balance of an Amazon floodplain lake has been performed for only one lake (L. Calado near Manacapuru; Lesack and Melack, 1995). Based on a Muskingum analysis, Richey et al. (1989) estimated that up to $30 \%$ of the discharge of the Amazon River is routed through the floodplain along a $2000 \mathrm{~km}$ reach between Sao Paulo de Olivença and Óbidos.

In our study, we measured and modelled water fluxes associated with a floodplain segment located in the lower part of the Amazon River, the floodplain of Lago Grande de Curuaí near Óbidos (Brazil). This floodplain contains large lakes connected to the mainstem river by several channels and is representative of the floodplain located in the downstream part of the Amazon River (Hess et al., 2003; Sippel et al., 1992). For 6 years, in the framework of the HyBAm (Hydrology and Geochemistry of the Amazonian Basin, IRDCNPq http://www.mpl.ird.fr/hybam/) research program, hydrological and geochemical conditions have been investigated (e.g., Barroux et al., 2003; Bonnet et al., 2005; Maurice-Bourgoin et al., 2005; Moreira-Turcq et al., 2004, 2005). Our measurements and analyses allow calculation of the hydrologic residence time of the floodplain segment, an estimation of the contributions of different sources of water to the floodplain, and provide a general framework for river-floodplain studies.

\section{Materials and methods}

\section{Study area}

The study site is the floodplain of Lago Grande de Curuaí (between $56.10^{\circ} \mathrm{W}$ and $55.00^{\circ} \mathrm{W}$ from upstream to down- stream, and $2.3^{\circ} \mathrm{S}$ and $1.9^{\circ} \mathrm{S}$ ), a floodplain segment located in the downstream reach of the Amazon River near Óbidos $\left(1^{\circ} 54.08^{\prime} \mathrm{S}, 55^{\circ} 31.116^{\prime} \mathrm{W}\right.$, Pará, Brazil), the location of a primary gauging station (Fig. 1).

The floodplain is delimited to the north by the Amazon River and to the south by the "terra firme", and is composed of several interconnected lakes temporally or permanently connected to the Amazon mainstem by small channels.

\section{Available data}

\section{Digital elevation model}

A digital elevation model (DEM) of the floodplain was made using several approaches. For the areas never flooded but located within the floodplain, Shuttle Radar Topography Mission data (SRTM) (Rabus et al., 2003) were used. Local inaccuracies of SRTM data are due to backscatter from plant canopies, but vegetation located in the unflooded portion of the floodplain is mainly herbaceous and does not cause a significant error. For the aquatic-terrestrial transition zone (ATTZ, sensu Junk, 1997), time series analysis of 21 JERS-1 images acquired between February 1993 and May 1997 was performed (Martinez and Le Toan, 2007). Inundated area on each date was related to water level measured at the Curuaí gauge. The water level range covered by the images was about $95 \%$ of the range of water level recorded at Curuaí since 1982, and images were well distributed over the stages. The comparison of the flooded area between two successive images acquired at water level $Z_{i}$ and $Z_{i+1}$ enabled the elevation $Z$ in the zone $Z_{i}<Z<Z_{i+1}$ to be retrieved. Repeating the comparison for all available images allowed construction of the ATTZ DEM. Since the Curuaí water level gauge was located within the main lake on the floodplain, we did not have to take into account a possible water level difference between the floodplain and the river as reported by Alsdorf et al. (2000). Classification accuracy for flooded area based on JERS-1 imagery has been estimated to be $30 \%$ (Martinez and Le Toan, 2007). For areas always inundated, we used depths recorded during field campaigns using an acoustic doppler current profiler. The three DEMs were merged, and areas were computed within ARCGIS using UTM projection. A linear regression was adopted between the lake surface $S_{\mathrm{L}}\left(\mathrm{km}^{2}\right)$ and the lake surface elevation $Z_{L}(m)$ after statistical verification that the relationship was linear $(p=0.24$ with the null hypothesis formulated as the relation is significantly non linear). The relationship is as follows with $90 \%$ confidence bands:

$S_{\mathrm{L}}=(-35 \pm 65)+(216 \pm 8) Z_{\mathrm{L}}$.

The flooded area ranged between $575 \mathrm{~km}^{2}$ and $2090 \mathrm{~km}^{2}$ as water levels varied between $3.03 \mathrm{~m}$ and $9.61 \mathrm{~m}$, the maximum and minimum recorded in Curuaí since 1997. The maximum floodable area delimited by the boundary between terra firme and the Amazon, is $2430 \mathrm{~km}^{2}$, corresponding to a water level in Curuaí of about $11.5 \mathrm{~m}$. The local wa- 


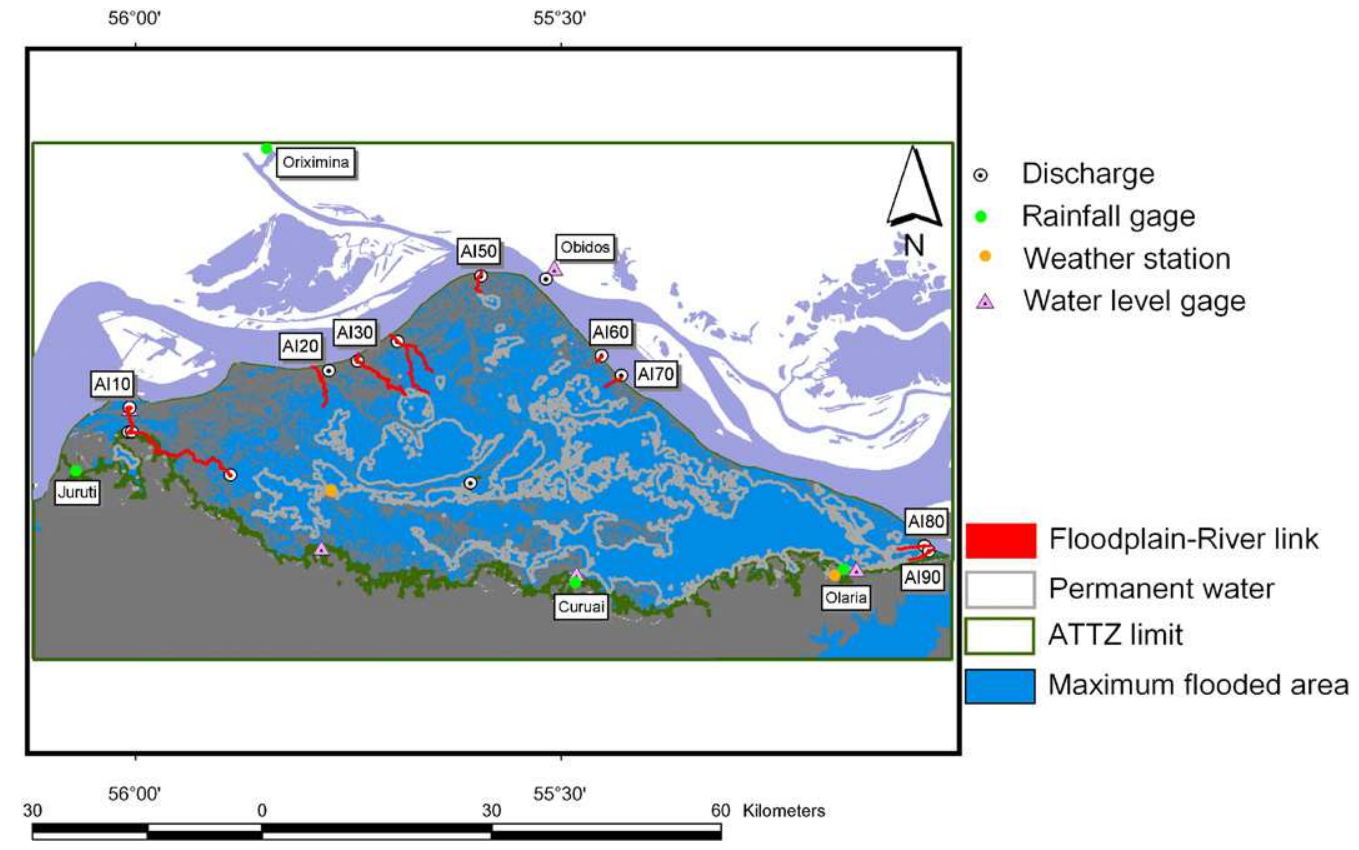

Figure 1 Map of the site. Location of daily water level measurements are indicated with triangles, sites with flow rate measurements during field campaigns are indicated with squares which mark the mouths of the channels, locations of rainfall gauges are indicated with circles. Meteorological stations were installed at Olaria and near the Lago do Sale during 2004, and are indicated as open circles. Due to the satellite resolution, channels in particular in the western part of the map are not visible, and their locations were deduced from GPS measurements.

tershed located south of the floodplain was extracted from the SRTM using Geo-HMS ArcView extension (UACE, 2003) and, has a total area of $1370 \mathrm{~km}^{2}$ and is mostly covered by evergreen forest.

\section{Water level}

Daily water level was recorded in a western connection channel (namely Ponto Seguro $\left(2^{\circ} 4.416^{\prime} \mathrm{S}, 56^{\circ} 0.348^{\prime} \mathrm{W}\right)$, denoted Al10 in Fig. 1 and hereafter) connecting the floodplain with the Amazon River and in two locations inside the floodplain, at Curuaí $\left(2^{\circ} 16.12^{\prime} \mathrm{S}, 55^{\circ} 28.84^{\prime} \mathrm{W}\right)$ and Tabatinga do Sale $\left(2^{\circ} 15.52^{\prime} \mathrm{S}, 55^{\circ} 40.2^{\prime} \mathrm{W}\right)$ (named AT10 in Fig. 1 and hereafter). In addition, the Agencia Nacional das Aguas (ANA) provided daily water levels recorded at Óbidos $\left(1^{\circ} 54.08^{\prime} \mathrm{S}, 55^{\circ} 31\right.$. $\left.116^{\prime} \mathrm{W}\right)$, Parintins $\left(2^{\circ} 37.31^{\prime} \mathrm{S}, 56^{\circ} 37.32^{\prime} \mathrm{W}\right)$, located $167 \mathrm{~km}$ upstream Óbidos along the Amazon River, and Santarém $\left(2^{\circ} 25.93^{\prime} \mathrm{S}, 54^{\circ} 41.45^{\prime} \mathrm{W}\right)$, located $123 \mathrm{~km}$ downstream of Óbidos. The water level series is described by Callède et al. (2001) and retrieved from the Hybam project web-site (http://www.mpl.ird.fr/hybam/). All the water level gauging stations were levelled with the help of satellite radar altimetry data (Topex/Poseidon, Envisat) and satellite laser altimetry (ICESat). Depending on the sensor type, the retracking algorithm and the distance between the satellite track and the water level gauging station to be levelled, the absolute uncertainty can vary between less than $10 \mathrm{~cm}$ to more than $1 \mathrm{~m}$, and in our study the absolute uncertainty was less than $0.75 \mathrm{~m}$ (Cauhope, 2004).

Water levels at the mouths of the mainstem-river nonmonitored channels (AI20 to Al80 in Fig. 1) are required for our data analysis (Section "Analyses"). These levels were determined by interpolation of the water levels re- corded at the stations with measurements, assuming a linear profile in the Amazon River mainstream along the Parintins-Óbidos segment, and the Óbidos-Santarém segment. In order to estimate the absolute error induced by the linear interpolation along the Amazon River mainstem, we compared the measurements at Óbidos with the stages obtained at Óbidos from the linear interpolation between Parintins and Santarém. The standard deviation between the two sets of values ranges from 0 to $22 \mathrm{~cm}$ with a mean value of $5 \mathrm{~cm}$ and a mean of the difference of $-6 \mathrm{~cm}$.

\section{Discharge}

Field campaigns during low and high water each year and occasionally at other times were conducted from 1999 to 2003 to determine discharge in the major channels connecting the floodplain to the mainstream river. An acoustic doppler current profiler (ADCP $1200 \mathrm{~Hz}$, WorkHorse Rio Grande ${ }^{T M} R D$ Instruments) was used to make the flow rate measurements. Discharge was estimated from at least 4 cross-section measurements with an error of about $5 \%$. Discharges in the Amazon River were computed from the rating curve established for the Óbidos stage. This relationship, initially proposed by Jaccon (1987) was improved by Callède et al. (2001), Filizola and Guyot (2004) using measurements with a 300 and $600 \mathrm{~Hz}$ ADCP (WorkHorse Rio Grande ${ }^{\mathrm{TM}} \mathrm{RD}$ Instruments) (Callède et al., 2000). Based on statistical analysis of the long-term discharge series calculated for the Óbidos stage from 1968 and 1999 performed by Callède et al. (2002), the peak flood discharge reached during 1999 corresponds to a flood with a return period ranging between 5 and 10 years, while the minimum flow recorded during low water in 1997 has a return period of 10 years. 


\section{Rainfall}

Rainfall was recorded daily at three sites: Curuaí $\left(2^{\circ} 16^{\prime} 7^{\prime} \mathrm{S}\right.$, $\left.55^{\circ} 2851^{\prime \prime} \mathrm{W}\right)$, Oriximiná $\left(1^{\circ} 45^{\prime} 37^{\prime \prime} \mathrm{S}, 55^{\circ} 51^{\prime} 43^{\prime \prime} \mathrm{W}\right)$ and Juruti $\left(2^{\circ} 9^{\prime} 8^{\prime \prime} \mathrm{S}, 56^{\circ} 5^{\prime} 15^{\prime \prime} \mathrm{W}\right)$ (Fig. 1) with manually read gauges $\left(400 \mathrm{~cm}^{2}\right.$ orifice size with a total capacity of $5000 \mathrm{~cm}^{3}$ (125 mm of rain) and a resolution of $0.2 \mathrm{~mm}$ ).

Compared with the average of the 76-year record of rainfall at Obidos, which is $2033 \mathrm{~mm}$ for all the water years taken from November to October, water year 1997-1998 was below average with a total amount of 1418 at Óbidos, and water years 1998-1999 and 1999-2000 were above average with totals of 2600 and $3238 \mathrm{~mm}$, respectively. The other water years studied were approximately average with totals of 2427, 2116 and $2470 \mathrm{~mm}$ for water years 2000-2001, 2001-2002, 2002-2003, respectively.

Rainfall recorded at the different locations shows no statistically significant spatial variability on an annual basis, but does vary significantly on a monthly basis. Thiessen polygons were computed using ArcView extension, in order to distribute daily precipitation over the study area.

Due to the small number of rain gauges, uncertainties in rainfall data are difficult to fully evaluate. They were assumed equal to 0.5 .

\section{Evaporation}

Potential evaporation was calculated from an empirical formula for both open-water and non-flooded areas located in the ATTZ proposed by Riou (1975) given as follows:

$\mathrm{ETP}=0.3 T_{\mathrm{m}}-5.9$

where ETP is the potential evapotranspiration $\left(\mathrm{mm} \mathrm{day}^{-1}\right)$ and $T_{\mathrm{m}}$ is the monthly averaged maximum temperature $\left({ }^{\circ} \mathrm{C}\right)$ measured at the Santarém meteorological station. To evaluate this simple formula, we compared it with evaporation estimated according to a mass transfer formula given in Bonnet et al. (2000) using meteorological data collected from March 2004 to March 2005. This formula follows the Dalton law $E=f(u)\left(e_{\mathrm{s}}-e_{\mathrm{a}}\right)$, in which $f(u)=2+0.9 u$, $u$ is the measured wind speed at two meters of elevation $\left(\mathrm{m} \mathrm{s}^{-1}\right) \cdot e_{\mathrm{s}}$ is the saturated vapour pressure at the temperature of the water, $e_{\mathrm{a}}$ is the effective vapour pressure. $e_{\mathrm{s}}$ $(\mathrm{kPa})$ depends on temperature $e_{\mathrm{s}}=611 \exp \left(\frac{17.27 T_{\mathrm{w}}}{T_{\mathrm{w}}+237.3}\right)$ with $T_{\mathrm{w}}$ the water temperature $\left({ }^{\circ} \mathrm{C}\right) . e_{\mathrm{a}}$ is related to measured relative humidity (\%) $H_{\mathrm{r}}=\frac{e_{\mathrm{a}}}{e_{\mathrm{s}}} 100$.

On an averaged monthly basis, values differ slightly between the two formulas, especially during November and December, but a good agreement is obtained on an annual basis. The mean cumulative value was $1359 \mathrm{~mm}_{\text {year }}^{-1}$ based on the Riou formula whereas it is $1373 \mathrm{~mm}_{\text {year }}{ }^{-1}$ using the mass transfer formula. The absolute uncertainty was fixed to 0.2 for the $M-C$ analysis (see below).

During average water years (2000-2001, 2001-2002, 2002-2003), evapotranspiration was about $58 \%$ of the total rainfall, for $50 \%$ of the rainfall during above average years and for more than $80 \%$ during below average years. Seasonal variations of evaporation were weak.

\section{Analyses}

The objectives of our analyses are to calculate exchanges of water between the Amazon River and its floodplain, to determine water residence time within the floodplain and to determine the mixture of various sources of water on the floodplain. The proposed model, called HEVa allows the computation of the floodplain water mass balance knowing the floodplain surface/stage relationship, water levels in the channels, precipitation and calculated monthly average evapotranspiration, and is similar to the approach used by Lesack and Melack (1995).

At each daily time step $\Delta t(d)$, the hydrologic mass balance of the floodplain is expressed as

$V_{\mathrm{L}}^{t+1}=V_{\mathrm{L}}^{t}+\left(Q_{\mathrm{R}}-Q_{\mathrm{E}}+Q_{\mathrm{wN}}+Q_{\mathrm{wS}} \pm Q_{\mathrm{G}} \pm \sum_{i} Q_{\mathrm{ci}}\right) \Delta t$

where $V_{\mathrm{L}}$ is the volume $\left(\mathrm{m}^{3}\right)$ of the flooded area, the superscript $t$ or $t+1$ indicating the time step, $\sum_{i} Q_{c i}$ is the algebraic sum of discharge entering (positive sign) or leaving (negative sign) in each channel $i\left(\mathrm{~m}^{3} \mathrm{~d}^{-1}\right), Q_{R}$ is the rainfall $\left(\mathrm{m}^{3} \mathrm{~d}^{-1}\right)$ onto the flooded surface, $Q_{E}$ is the evaporation $\left(\mathrm{m}^{3} \mathrm{~d}^{-1}\right), Q_{\mathrm{wN}}$ is the runoff from floodplain's watersheds located in the ATTZ (their surface is determined as the difference between the maximum floodable area and the flooded area), $Q_{w s}$ is the runoff from the southern upland watersheds and $Q_{G}\left(\mathrm{~m}^{3} \mathrm{~d}^{-1}\right)$ is the seepage into or from the groundwater system. To simplify the notation, the superscript $t$ is removed from each of the flux terms.

The quantification of these water fluxes is explained below. Hence, knowing an initial condition, it is possible to compute the water level of the following time step and to deduce from the stage/areas and stage/volume the new surface and volume of the floodplain. For computational purpose, the time step can be reduced, but the model results are reported as daily values.

The discharge $Q_{c i}\left(\mathrm{~m}^{3} \mathrm{~d}^{-1}\right)$ in each channel $i$ linking the floodplain and the Amazon River is computed by a Strickler-Manning-like formulation for a rectangular section, but instead of using the bottom slope of the channel, the free surface slope of the channel is introduced in the formulation.

$Q_{\mathrm{ci}}=K_{\mathrm{s}} \sqrt{S_{\mathrm{ci}}} L H_{\mathrm{ci}}^{5 / 3}$

where $K_{s}$ is the roughness coefficient, $s_{\mathrm{ci}}=\frac{\left|Z_{\mathrm{ci}}-Z_{\mathrm{L}}\right|}{L}$ is the free surface slope between the upstream mouth of the channel $i$ (elevation $Z_{\mathrm{ci}}$ ) and the flooded area (elevation $Z_{\mathrm{L}}$ computed by the model at each time step). $l$ is the channel length $(\mathrm{m})$ and $H_{\mathrm{ci}}$ is the mean depth of the channel $(\mathrm{m})$. Flow direction is deduced from the sign of $s_{\mathrm{ci}}$.

As explained below in the Monte Carlo analysis, the slope along the Amazon River was allowed to vary from $2.35 \mathrm{~cm} \mathrm{~km}^{-1}$ to $0.6 \mathrm{~cm} \mathrm{~km}^{-1}$ with a mean value over the thousand simulations of $1.48 \mathrm{~cm} \mathrm{~km}^{-1} \pm 0.36$ for the Parintins-Óbidos segment and from $2.6 \mathrm{~cm} \mathrm{~km}^{-1}$ to $0.23 \mathrm{~cm} \mathrm{~km}^{-1}$ with a mean value over the thousand simulations of $1.37 \pm 0.47 \mathrm{~cm} \mathrm{~km}^{-1}$ for the Óbidos-Santarém segment. These two mean values are in good agreement with values given in Birkett et al. (2002) for the same area of study. The allowed range of slope introduced in the calculations incorporated the uncertainty in the altimetry. The water level in the flooded area was deduced from computation of the previous time step and only an initial value was required. 
Inputs from direct rainfall onto the surface of the flooded area are $Q_{R}=P S_{L} Q_{R}=P S_{L}$ with $P\left(m^{-1}\right)$ the rainfall, $S_{L}\left(m^{2}\right)$ the surface of the flooded area computed at the each time step, while $Q_{E}=E S_{L}$ with $E\left(\mathrm{~m} \mathrm{~d}^{-1}\right)$ the evaporation rate.

The runoff from the ATTZ is computed as

$Q_{W N}=\operatorname{Max}\left((P-E)\left(S_{B V N}-S_{L}\right), 0\right)$

where $S_{\mathrm{BVN}}\left(\mathrm{m}^{2}\right)$ is the maximal surface of the watershed including the flooded area located in the ATTZ. SL is the surface of the open-water area. As the floodplain wets and dries, the surface of the non flooded area varies. We assumed the same evaporation rate $E$ as for open water surface.

The runoff from the upland local watershed $Q_{w s}$ was assumed to be $60 \%$ of the precipitation as calculated in Lesack and Melack (1995)

$Q_{\mathrm{wS}}=0.6 P S_{\mathrm{BVS}}$

where $S_{\mathrm{Bvs}}$ is the upland local watershed area $\left(\mathrm{m}^{2}\right)$ and $P$ is the rainfall. At this stage, and without any data to constrain the model, we assumed that precipitation minus evaporation was transformed into runoff without any loss and without any time lag.

No data related with bank-seepage were acquired during the field trips. However, according to Darcy's law and assuming stationary flow conditions, the exchanged fluxes can be expressed as

$Q_{\mathrm{G}}=K L * \mathrm{~d} Z \frac{\mathrm{d} H}{\mathrm{~d} X}$

where $K$ is the permeability of the bank forming the porous media $\left(\mathrm{m} \mathrm{s}^{-1}\right), \mathrm{d} H$ is the water level difference between the Amazon River and the flooded area. $L$ is the contact-length along the Amazon River (m) (about $120 \mathrm{~km}$ ), dZ is the thickness of the alluvial groundwater system; as a first approximation, $\mathrm{dZ}$ is assumed constant and equal to the Amazon River depth (about $60 \mathrm{~m}$ at the Óbidos location). $\mathrm{d} X$ is the distance between the river and flooded area. This distance varies with time as the floodplain wets and dries and with space, as the distance between the Amazon River and the flooded area is varying from west to east along the Amazon River (see Fig. 1). As a first approximation, $\mathrm{d} X$ was assumed to linearly vary between a minimal value (obtained from the DEM during high water period) and a maximal value obtained during low water period. The bank permeability was assumed constant, equal to $10^{-2} \mathrm{~m} \mathrm{~s}^{-1}$.

At each time step, the water input and output from the flooded area are computed (Eq. (8)) and the volume (or the water level) for the new time step is deduced from the mass conservation equation (Eq. (9)).

$$
\begin{aligned}
& B=\left(\sum_{i} Q_{c i}\right)+Q_{R}+Q_{W N}+Q_{W S}+Q_{G}-Q_{E} \\
& V_{\mathrm{L}}^{t+1}=V_{\mathrm{L}}^{t}+B \Delta t \quad \text { or } \quad Z_{\mathrm{L}}^{t+1}=Z_{\mathrm{L}}^{t}+\frac{B \Delta t}{S_{\mathrm{L}}}
\end{aligned}
$$

The parameters requiring calibration include the roughness coefficient and channel geometry defined by width and bottom elevation and length, a rectangular section being assumed. However, as width and roughness coefficient $K s$ are expected to vary with water level, the model allows describing a connection as a set of channels with different width and roughness coefficients. The required inputs are the daily rainfall and the water level estimated at points connecting each connection with the Amazon River. These water levels were measured in one of the western channels (in Al10 in Fig. 1) and determined from water levels measured in the Amazon River in Parintins, Óbidos and Santarém assuming a linear profile of the river between these three locations.

Uncertainty analysis on input data was performed according to a Monte-Carlo $(\mathrm{M}-\mathrm{C})$ approach. We assumed that each input data came from a normal distribution $N(m, S D)$, with SD the absolute or relative uncertainty as mentioned in Section "Available data". A thousand simulations were done, absolute or relative error of input data SD being randomly chosen based on their allowed range of variation reported in the text (Section "Available data"). Model results uncertainties were appraised using the standard deviation computed from the 1000 simulations.

Table 1 Minimal, average, and maximal water levels $(\mathrm{m})$, open water surface $\left(\mathrm{km}^{2}\right)$ and volume $\left(\mathrm{km}^{3}\right)$ over the course of the

\begin{tabular}{|c|c|c|c|c|c|c|c|c|c|c|c|c|c|c|c|c|c|c|}
\hline \multirow[t]{3}{*}{ Year } & \multicolumn{6}{|c|}{ Water level } & \multicolumn{6}{|c|}{ Surface } & \multicolumn{6}{|c|}{ Volume } \\
\hline & \multicolumn{2}{|c|}{$\operatorname{Min}(\mathrm{m})$} & \multicolumn{2}{|c|}{$\begin{array}{l}\text { Average } \\
(\mathrm{m})\end{array}$} & \multicolumn{2}{|c|}{$\operatorname{Max}(\mathrm{m})$} & \multicolumn{2}{|c|}{$\operatorname{Min}\left(\mathrm{km}^{2}\right)$} & \multicolumn{2}{|c|}{$\begin{array}{l}\text { Average } \\
\left(\mathrm{km}^{2}\right)\end{array}$} & \multicolumn{2}{|c|}{$\operatorname{Max}\left(\mathrm{km}^{2}\right)$} & \multicolumn{2}{|c|}{$\operatorname{Min}\left(\mathrm{km}^{3}\right)$} & \multicolumn{2}{|c|}{$\begin{array}{l}\text { Average } \\
\left(\mathrm{km}^{3}\right)\end{array}$} & \multicolumn{2}{|c|}{$\operatorname{Max}\left(\mathrm{km}^{3}\right)$} \\
\hline & $m$ & $\mathrm{SD} \%$ & $m$ & $\mathrm{SD} \%$ & $m$ & SD\% & $m$ & SD\% & $m$ & $\mathrm{SD} \%$ & $m$ & SD\% & $m$ & $\mathrm{~S} \%$ & $m$ & SD\% & $m$ & SD\% \\
\hline $97-98$ & 2.7 & 0.2 & 5.4 & 4.5 & 7.9 & 3.0 & 627 & 5.6 & 1148 & 7.6 & 1681 & 5.2 & 0.4 & 45.1 & 3.0 & 11.7 & 6.3 & 5.7 \\
\hline $98-99$ & 3.1 & 3.3 & 6.7 & 4.5 & 9.6 & 3.2 & 662 & 6.9 & 1426 & 7.6 & 2027 & 5.3 & 0.6 & 30.6 & 4.9 & 10.1 & 9.3 & 5.3 \\
\hline 99-00 & 3.0 & 5.5 & 6.7 & 4.6 & 9.2 & 3.4 & 661 & 7.8 & 1435 & 7.7 & 1956 & 5.6 & 0.6 & 34.9 & 4.8 & 10.1 & 8.7 & 5.6 \\
\hline $00-01$ & 3.0 & 2.3 & 6.6 & 4.5 & 9.1 & 3.3 & 659 & 6.1 & 1400 & 7.6 & 1929 & 5.5 & 0.6 & 30.8 & 4.6 & 10.2 & 8.4 & 5.6 \\
\hline $01-02$ & 3.1 & 5.1 & 6.8 & 4.6 & 8.7 & 3.6 & 665 & 8.0 & 1438 & 7.7 & 1846 & 6.0 & 0.6 & 31.8 & 4.8 & 10.2 & 7.7 & 6.3 \\
\hline $02-03$ & 3.2 & 4.8 & 6.1 & 5.0 & 8.5 & 3.6 & 696 & 7.8 & 1305 & 7.9 & 1794 & 5.8 & 0.7 & 27.5 & 3.9 & 10.9 & 7.2 & 5.9 \\
\hline Average & \multicolumn{2}{|c|}{3.0} & \multicolumn{2}{|c|}{6.4} & \multicolumn{2}{|c|}{8.8} & \multicolumn{2}{|c|}{662} & \multicolumn{2}{|c|}{1359} & \multicolumn{2}{|c|}{1872} & \multicolumn{2}{|c|}{0.6} & \multicolumn{2}{|c|}{4.4} & \multicolumn{2}{|c|}{7.9} \\
\hline SD\% & \multicolumn{2}{|c|}{5.3} & \multicolumn{2}{|c|}{8.6} & \multicolumn{2}{|c|}{6.7} & \multicolumn{2}{|c|}{3.3} & \multicolumn{2}{|c|}{8.4} & \multicolumn{2}{|c|}{6.7} & \multicolumn{2}{|c|}{18.2} & \multicolumn{2}{|c|}{16.8} & \multicolumn{2}{|c|}{13.9} \\
\hline
\end{tabular}
water years and related standard deviations 


\section{Results and discussion}

\section{Model calibration and validation}

Our analyses were applied to the period from September 1, 1997 to December 15, 2003 enabling us to examine six consecutive water years.

Six connections were incorporated and correspond to connections AI10; AI20, Al30, Al40, Al70 and Al80 (Fig. 1). In order to take into account changes in geometry with water level, each of the connections is described as a set of two channels differing by their cross-section. Two shallow channels were added to describe over-bank flooding in the eastern part of the floodplain. Channel lengths were deduced from satellite imagery and field data; as the channel geometry is simplified, width and depth acquired during field campaigns needs a slight adjustment in order to minimize the mean absolute difference between the water level measured at Curuaí and the computed water levels in the flooded area. Of the parameters requiring calibration, the roughness coefficient was the least sensitive; it was fixed at $\mathbf{4 0}$ for all channels except the shallowest for which we used a value of 20 . The model was calibrated against water levels measured at Curuaí and checked against discharges measured at floodplain-Amazon River connecting channel mouths for water year 2001-2002. It was validated against data from the other years.

One thousand simulations were performed and the results presented hereafter are the average of the thousand simulations and related uncertainties are appraised by their standard deviation.

\section{Water level}

Good agreement was found between the simulated and measured water levels. Maximal daily absolute difference between measured and computed water levels is less than $40 \mathrm{~cm}$. On an annual basis, the mean absolute difference did not exceed $7 \mathrm{~cm}$ for the six water years from 1999 to 2003 with about $5 \mathrm{~cm}$ of standard deviation. Results are slightly less satisfying for the first simulated water year with a mean absolute difference of $8 \pm 9 \mathrm{~cm}$. Minimum, average and maximum stage height over the course of the water years are reported in Table 1 for each year as well as the corresponding lake surface area and volume ranges over the course of the water year. Standard deviations deduced from Monte-Carlo analysis are also reported.

Based on the six water years, over the course of the water year, the absolute water level ranged from $3.0 \pm 0.2 \mathrm{~m}$ to $8.8 \pm 0.6 \mathrm{~m}$, flooded area ranged from $662 \pm 22 \mathrm{~km}^{2}$ to $1872 \pm 125 \mathrm{~km}^{2}$, the floodplain volume ranged from $0.6 \pm 0.1$ $\mathrm{km}^{3}$ to $7.9 \pm 1.1 \mathrm{~km}^{3}$ (Table 1 ). However, significant interannual variations were observed between the six water years. The maximum water level ranged from $7.9 \pm 0.2 \mathrm{~m}$ to $9.6 \pm$ $0.3 \mathrm{~m}$, the maximum flooded area ranged from $1681 \pm 87$ $\mathrm{km}^{2}$ to $2027 \pm 107 \mathrm{~km}^{2}$, the maximum volume ranged from $6.3 \pm 0.4$ to $9.3 \pm 0.5 \mathrm{~km}^{3}$. Inter-annual variations were larger during the high water periods than during the low water periods.

\section{Discharge}

For most of the floodplain-Amazon River channels, the computed flow rate was in good agreement with the ADCP measurements (Fig. 2). Upstream channels Al 10-Al 70 are only a source of water for the floodplain, whereas the downstream channel Al80 behaves mainly as an outflow. Each year, Amazon River water starts invading the floodplain in mid-December or early January (during below average years) by flooding channels Al10 and Al70. Flooding channels Al20 and Al30 starts later in early March because of shallower depths of these channels. Fluxes between the Amazon River and the floodplain at the downstream channel (Al80) are driven by small differences between the rate of rise
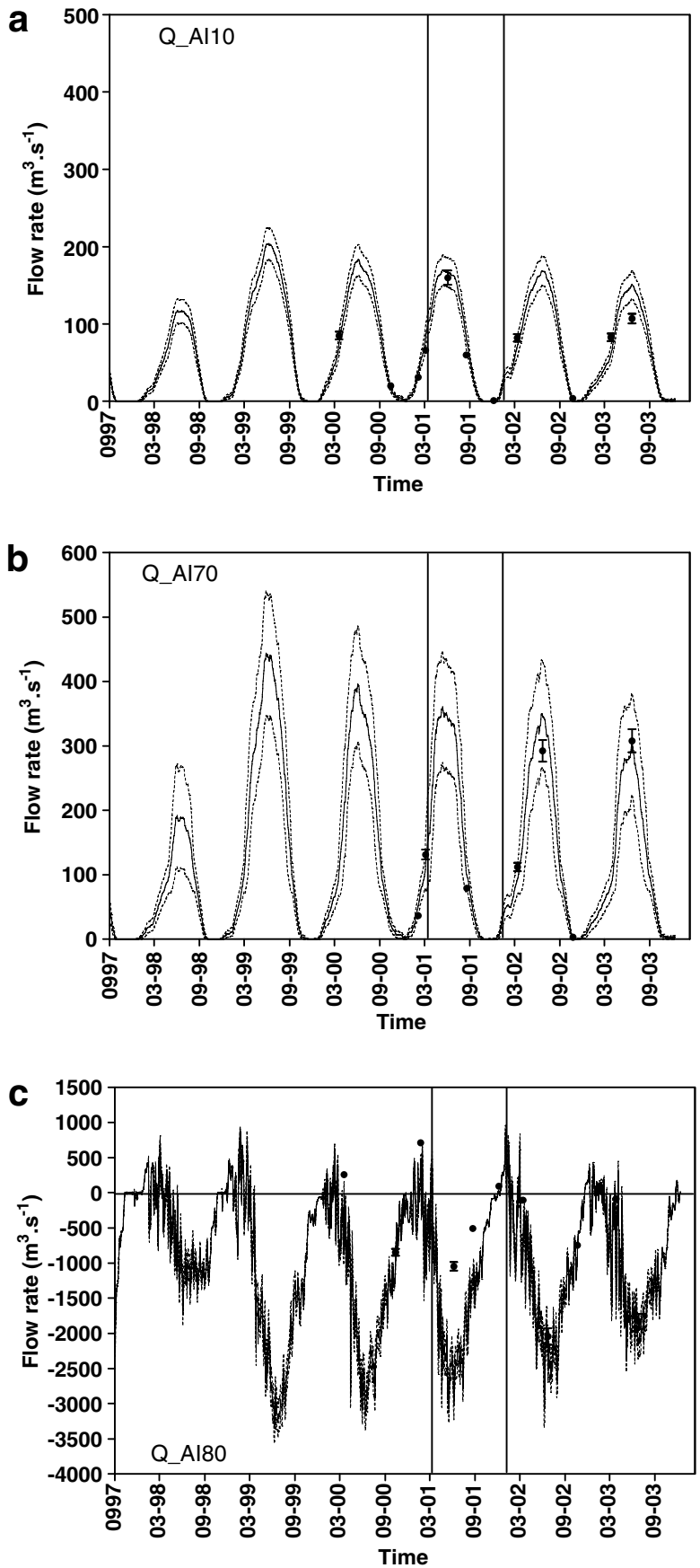

Figure 2 Modeled (solid line for the mean, dashed lines for the min and max of the $M-C$ analysis) and measured (points) flow rates in different connecting channels. 
occurring in the floodplain and the river and both the direction and discharge rate are quite variable. For normal years, the temporal distribution of water flux through the connection indicates an inflow from the Amazon River during January, followed by a period with flow directions changing from inflowing to outflowing from February to end of April. The flow direction changes into outflowing from end of April to end of October. For below average runoff water years, the temporal distribution of water flux through this connection indicates an inflow from the end of December to midJanuary. From mid-January to mid-May, the direction of flow alternates from inflowing to outflowing. From midMay to early October, the water lake was discharging into the Amazon River. From October to the next period of rising water, the only loss of water from the lake was through evaporation and seepage into groundwater. For above aver- age years, inflow starts at the end of November and continues to end of March; direction of flow changes to outflow from the end of March to November. The period of alternating inflows and outflows was shortened.

Largest relative uncertainties occur at smallest discharges, the median values being 0.21 and 0.19 for inflow and outflow, respectively (Fig. 3). For the downstream channel, relative uncertainties are more variable than for the upstream channels and are mainly related with discharges computed during the period of alternating inflows and outflows.

The variability in flow direction, and, in particular, the periods of alternating flows could be associated with large amounts of rainfall directly onto the surface of the lake or local runoff, thus, confirming the influence of local rainfall on the floodplain-river mainstream fluxes which was
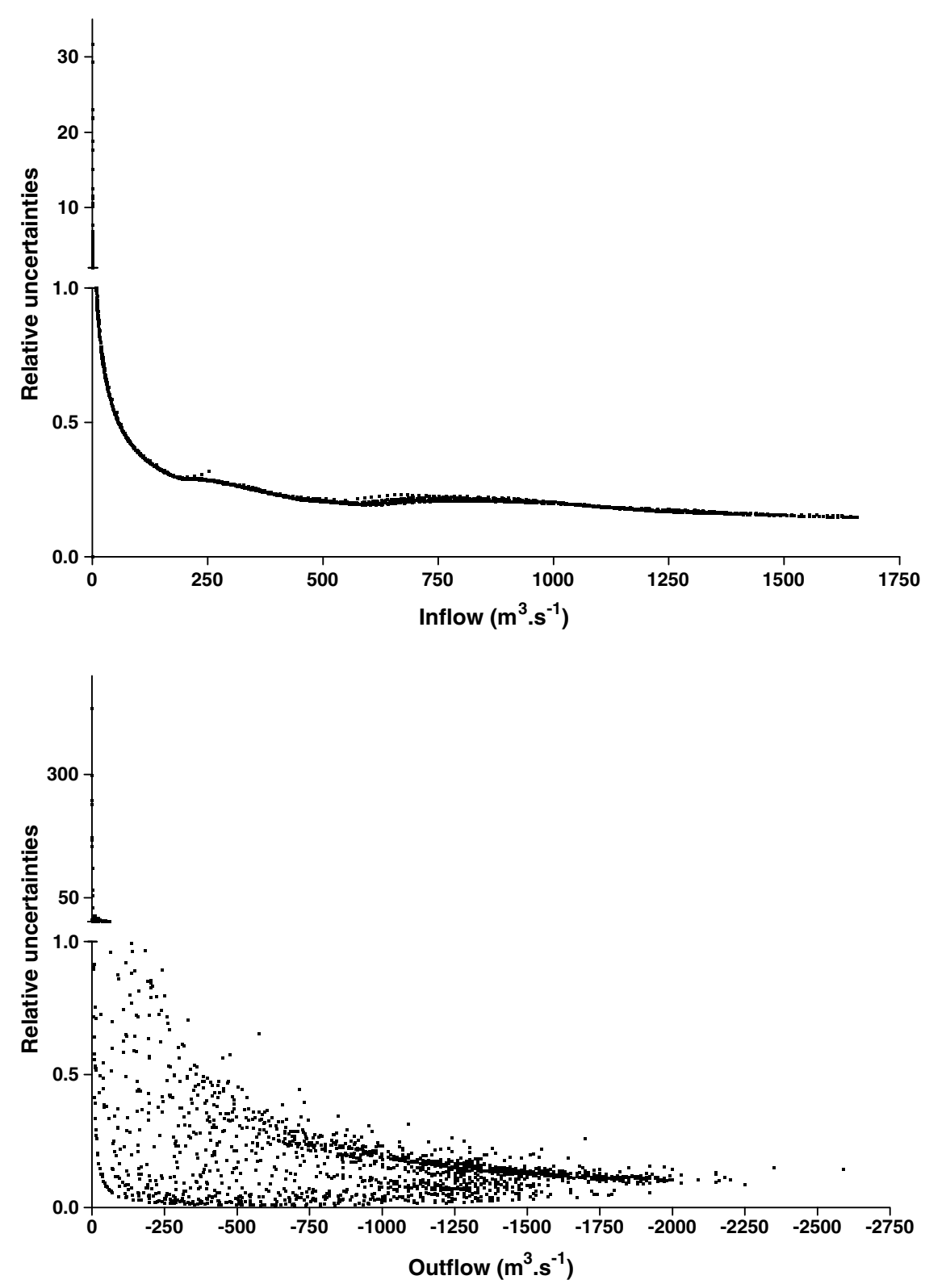

Figure 3 Distribution of inflow and outflow relative uncertainties. 


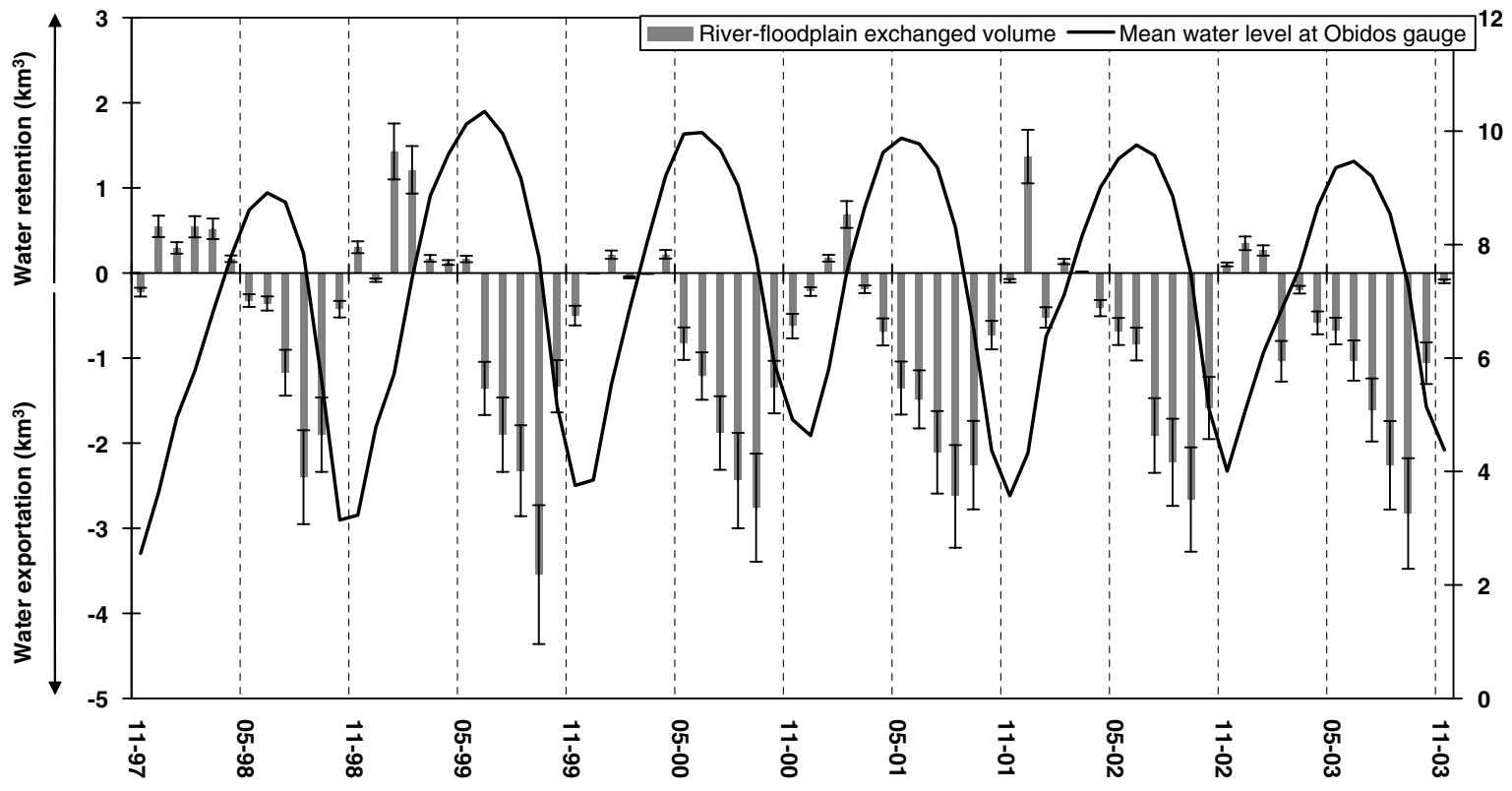

Figure 4 Monthly cumulative volume exchanged between the floodplain and the Amazon River mainstem. A positive value indicates water retention.

observed for Lake Calado, a smaller floodplain segment west of Manaus (Lesack and Melack, 1995). However, during this period, discharge uncertainties are large and additional data would be required to confirm this hypothesis.

\section{Temporal dynamics of the floodplain - river mainstem exchanges}

Generally, water storage within the floodplain started between December and February, and lasted until June (Fig. 4). From this time until the end of the water year, water was exported from the floodplain into the river. Maximum export occurred each year during August and September. Relative uncertainty of the cumulative net water balance is about $15 \%$.

\section{Temporal dynamics of the lake water mixture}

Study of the water year 2001-2002. Cumulative volume of the water flux components: The results for water year 2001-2002 indicate that the main component of water in the lake was from the river, the local rainfall and runoff from upland local watershed and from watershed located in the ATTZ constituting the second and third most important sources of water for the lake (Fig. 5). From the beginning of the water year to January 20,2002, the only loss of water was through evaporation. From this date to July 5 , 2002, the water level in the lake continued to rise despite significant outflow into the Amazon River. By mid-September the lake was making a net contribution to the river. At the end of the year, the total volume from the Amazon River was 3.7 times the maximum volume reached by the lake $\left(7.7 \times 10^{9} \mathrm{~m}^{3}\right)$, whereas the outflow into the river represented 4.5 times this volume. By the end of July, local runoff from watersheds located in the ATTZ and from upland local watersheds was similar and was about 0.2 times the maximum volume reached by the lake, whereas rainfall represented 0.4 times this volume. The input through bank seepage was 0.1 times the maximum volume of the lake, but part of this volume was returned to the groundwater by the end of the year. Seepage from groundwater and runoff from the upland watershed mainly occurs during the period of rising water from the end of December through the end of July. These computations are summarized in Table 2. The annual retention of water from all sources is defined as $R_{\mathrm{w}}=\left(\sum \ln -\sum\right.$ Out $) \Delta t$. The term $\sum \ln$ is the sources of water from the river, from the rainfall onto the surface of the lake, from the runoff from the ATTZ and from the lumped source; the term $\sum$ Out is the loss of water into the river, into the groundwater system and the loss by evaporation.

\section{Temporal mixture in the lake}

In order to evaluate the mixture of water types present in the lake over the course of the 2001-2002 water year, we adopted the approach used by Lesack and Melack (1995). Initially, the mixture was dominated by the mixture from the end of the previous year, denoted $\sum_{0}$ (Fig. 5b). From the beginning of the water year and to mid-December, the floodplain mixture was dominated by the water from the previous year. In early January, the Amazon River dominated the mixture $(64 \%)$. From this date until the beginning of April, the river water contribution slightly decreased while contributions from watersheds and direct rainfall increased. By the end of year, river water represented $78 \%$ of the mixture. By mid-April water from rainfall ( $P$ in Fig. 5b) constituted as much as $17 \%$ while contributions from local upland watershed (wS in Fig. 5b) and from watershed located in the ATTZ ( $W N$ in Fig. $5 b$ ) were maximum by the end of February and constituted $14 \%$ and $15 \%$, respectively. The contribution from the groundwater reservoir ( $G$ in Fig. 5b) was maximum at the end of December reaching $5 \%$ of the mixture. 

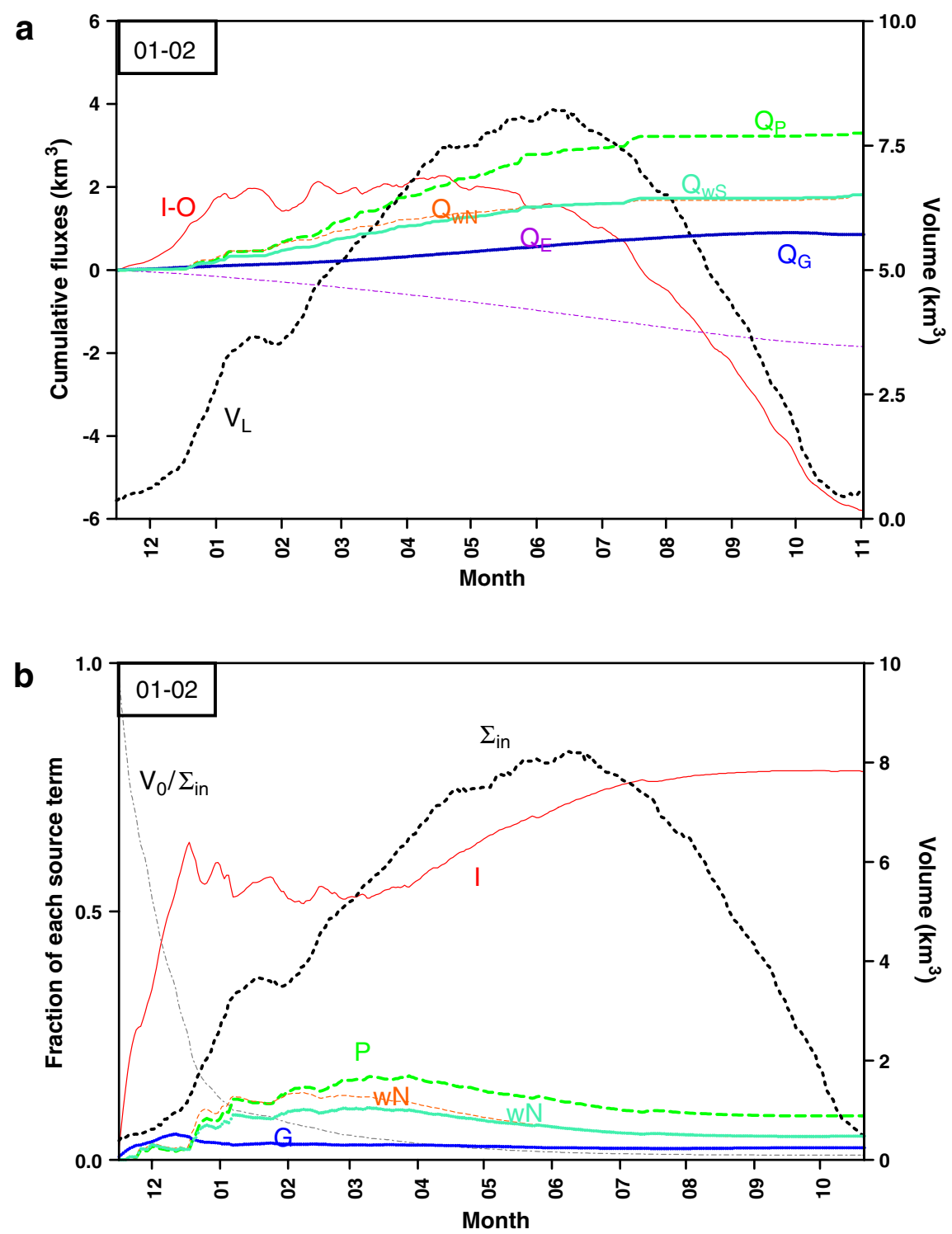

Figure 5 (a) Cumulative fluxes of water on the floodplain for water year 2001-2002 (November 29, 2001 to November 27, 2002). $I-O$ denotes the inflows minus outflow cumulative fluxes from the Amazon River. $Q_{w N}$ is the cumulative runoff from the watershed located in the ATTZ, $Q_{w s}$ is the cumulative flux related with the upland local watershed, $Q_{E}$ is the cumulative evaporation flux, $Q_{P}$ is the cumulative precipitation flux and $Q_{G}$ is the cumulative flux related with bank seepage. The volume of water on the floodplain is also shown. Inflowing fluxes have a positive sign. (b) Fraction of total input contributed by each source of water and total inputs in the floodplain during water year 2001-2002. $V_{\mathrm{o}}$ is the volume of the floodplain at the beginning of the water year.

\section{Inter-annual variation}

\section{Cumulative volume of each water flux components}

Inter-annual variations are evident especially for maximal volumes reached each year which vary from 6.3 to $9.3 \mathrm{~km}^{3}$ (Table 1). Fluxes with the Amazon River vary by more than $40 \%$ among years (Table 2 ). At the end of each year, the total volume from the Amazon River represented between 2.1 and 5.6 times the maximal volume reached by the floodplain each year, while volume exported to the river varied between 2.8 and 6.5 times this volume. The volume received from bank seepage was about 0.1 times the maximum floodplain volumes reached each year, and was about 4 times the volume exported by seepage into the groundwater system.
The total volume from rainfall and local runoff from upland local watershed and from ATTZ does not exceed 0.5 and 0.3 times the maximal volume reached each year by the floodplain, respectively. River water retention ranges from -4.2 to $-7.3 \mathrm{~km}^{3}$ and corresponds to a net source for the Amazon River. Retention of water from all sources varied from -0.5 to $0.5 \mathrm{~km}^{3}$.

\section{Temporal mixture in the lake}

Inter-annual variation is strongest during the rising period (Fig. 6). In 1997-1998, the lake water mixture was dominated by mixture from the previous year and main sources of water were direct precipitation and runoff from watersheds. River inflow represented only 2.1 times the maximum 
Table 2 Cumulative volume related to inflow, outflow, rainfall, runoff, evaporation, and lumped term for seepage and upland runoff for each of the six water years

\begin{tabular}{|c|c|c|c|c|c|c|c|c|c|c|c|c|c|c|c|c|}
\hline \multirow[t]{3}{*}{ Year } & \multicolumn{10}{|c|}{ Source terms $\left(\mathrm{km}^{3}\right)$} & \multicolumn{6}{|c|}{ Sink terms $\left(\mathrm{km}^{3}\right)$} \\
\hline & \multicolumn{2}{|c|}{ Inflow } & \multicolumn{2}{|c|}{ Rainfall } & \multicolumn{2}{|c|}{ Runoff wN } & \multicolumn{2}{|c|}{ Runoff wS } & \multicolumn{2}{|c|}{ Seepage } & \multicolumn{2}{|c|}{ Outflow } & \multicolumn{2}{|c|}{ Evaporation } & \multicolumn{2}{|c|}{ Seepage } \\
\hline & $m$ & SD\% & $m$ & SD\% & $m$ & SD\% & $m$ & SD\% & $m$ & SD\% & $m$ & SD $\%$ & $m$ & SD\% & $m$ & SD\% \\
\hline \multicolumn{17}{|l|}{ (a) } \\
\hline $97-98$ & 13.3 & 20 & 2.4 & 30 & 1.8 & 40 & 1.6 & 40 & 0.7 & 20 & 17.6 & 19 & 1.6 & 13 & 0.4 & 20 \\
\hline $98-99$ & 55.6 & 16 & 3.4 & 30 & 1.8 & 40 & 1.9 & 40 & 0.6 & 20 & 60.8 & 13 & 2.1 & 13 & 0.4 & 20 \\
\hline $99-00$ & 40.6 & 19 & 4.0 & 30 & 2.2 & 40 & 2.3 & 40 & 0.7 & 20 & 47.3 & 13 & 1.9 & 13 & 0.1 & 20 \\
\hline $00-01$ & 36.8 & 19 & 3.9 & 30 & 2.1 & 40 & 2.2 & 40 & 0.6 & 20 & 44.2 & 13 & 1.8 & 13 & 0.1 & 20 \\
\hline $01-02$ & 28.6 & 18 & 3.3 & 30 & 1.8 & 40 & 1.8 & 40 & 0.9 & 20 & 34.4 & 14 & 1.8 & 13 & 0.0 & 20 \\
\hline $02-03$ & 22.6 & 19 & 3.8 & 30 & 2.2 & 40 & 2.2 & 40 & 0.9 & 20 & 29.5 & 15 & 1.9 & 13 & 0.0 & 20 \\
\hline Average & 32.9 & & 3.5 & & 2.0 & & 2.0 & & 0.7 & & 39 & & 2 & & 0.2 & \\
\hline \multirow[t]{3}{*}{ SD $\%$} & 45.0 & & 17.3 & & 11.5 & & 12.8 & & 17.0 & & 38.8 & & 7.8 & & 100.7 & \\
\hline & & & & & & & & \multicolumn{9}{|c|}{ Net balance Rw } \\
\hline & & & & & & & & $m$ & & & & & & & & SD\% \\
\hline
\end{tabular}

(b)

97-98

98-99

99-00

00-01

$01-02$

02-03

Average

SD\%
0.2

0.0

0.5

$-0.5$

0.1

0.2
60

60

60

60

60

60

Standard deviations were obtained from the $\mathrm{M}-\mathrm{C}$ analysis. A negative net balance indicates water export to the Amazon River. Rw is the water mass balance including all the source and sink terms. A positive value indicates water storage in the floodplain.

storage $\left(6.3 \mathrm{~km}^{3}\right)$ while outflow represented 2.8 times this volume. From the end of August to the end of the water year, the floodplain made a net contribution to the river of about $4.2 \mathrm{~km}^{3}$. By the end of the year, the volume that had entered the lake by runoff and rainfall onto the surface only accounted for 0.6 and 0.3 times the maximum storage and the volume from the groundwater system was about 0.1 times the maximum storage. This term is partially balanced by the seepage into the groundwater system which was 0.07 times the maximum volume of stored water.

During 1999-2000, the wettest year during our study, river inflow accounted for 4.7 times the maximum water storage in the lake $\left(8.7 \mathrm{~km}^{3}\right)$, while outflow accounted for 5.5 times this volume. By the end of the year, rainfall had contributed 0.5 the maximum storage while runoff from the tidal zone accounted for 0.3 this volume. Input from the groundwater system and southern runoff represented 0.08 and 0.3 times the maximum storage, respectively, while seepage into the groundwater system accounted for 0.01 times this volume. The lake water mixture was dominated successively by the lake water mixture from the previous year by the end of December. At this time runoff from watersheds located in the tidal zone started to dominate the lake water mixture through the beginning of February. From this time through the end of the year, the lake water mixture was mainly composed of river water which ac- counted for about $81 \%$ by the end of the year while direct rainfall and runoff represented $8 \%$ and $9 \%$, respectively. During this year, the floodplain made a net contribution to the Amazon River of about $6.7 \mathrm{~km}^{3}$.

When hydrologic conditions are average or above average, river inflow constituted the main source of water and dominated the lake water mixture during most of the water year. Direct rainfall and local runoff may dominate the water lake mixture during the rising period for below average years. Seepage from the groundwater system contributed each year less than $5 \%$.

Apart from the rising period of each year, exchanged volumes are of the same order of magnitude of the volume uncertainties and additional field data are necessary to correctly evaluate the contribution of the local upland watershed and the groundwater system as well as to reduce model uncertainties (Fig. 7).

\section{Water residence in the floodplain}

We computed annual residence time of water $T_{\mathrm{w}}$ computed as $T_{\mathrm{w}}=\frac{v_{t}}{\left(\sum \ln \right)_{t}}$. The term $\left(\sum \ln \right)_{t}$ is the sources of water from the river, from the rainfall onto the surface of the lake, from the runoff from the ATTZ and from the local upland watershed and from the groundwater system computed 

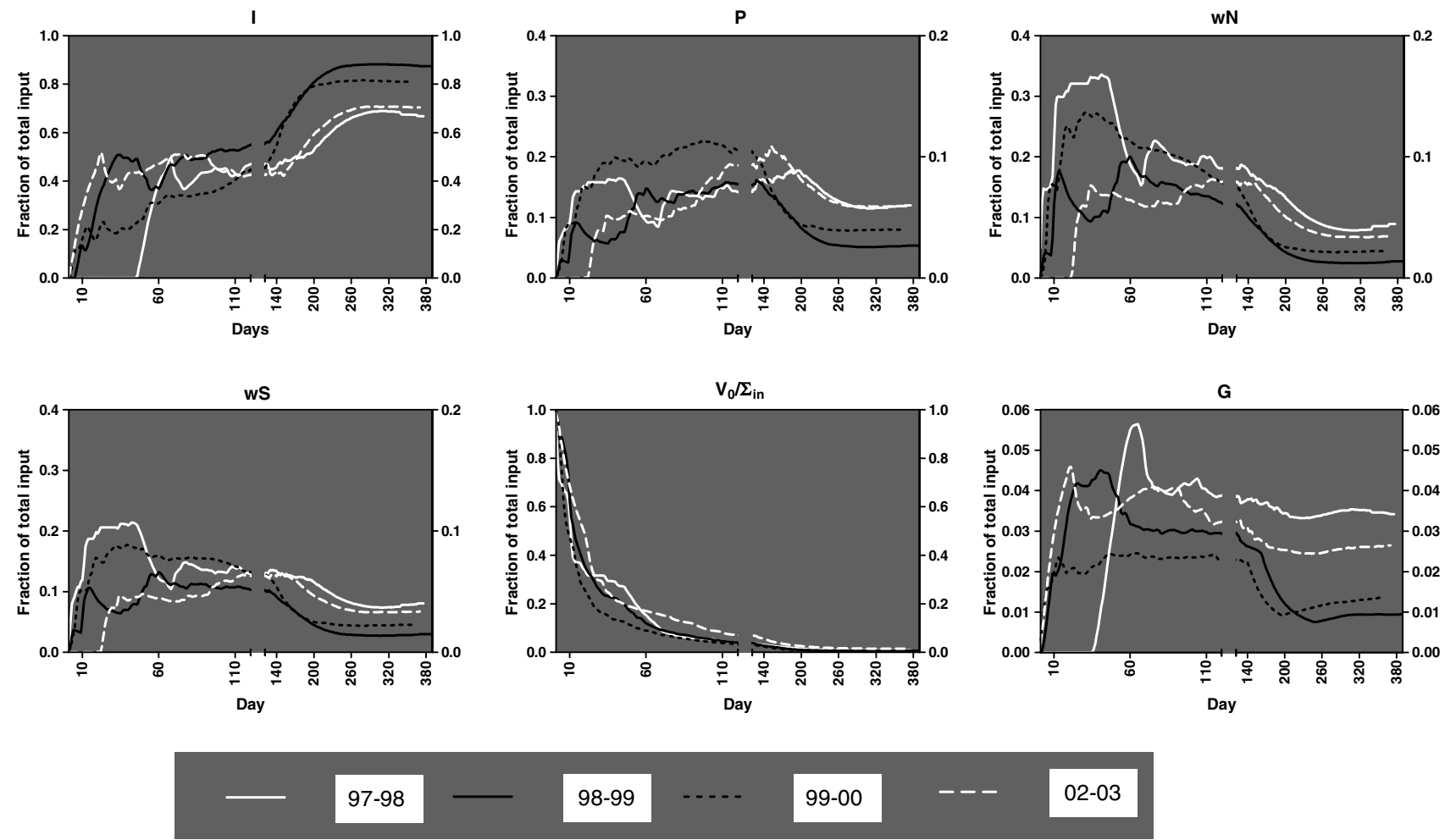

Figure 6 Fraction of total input contributed by inflow (upper left), by direct rainfall (upper middle), by runoff from watershed located in the tidal zone (upper right), by runoff from local upland catchments (bottom left) and by mixture from the previous year (bottom middle) and by bank seepage (bottom right) for a below average year 1997-1998, for above average years 1999-2000 and 1998-1999, and for an average year 2002-2003.

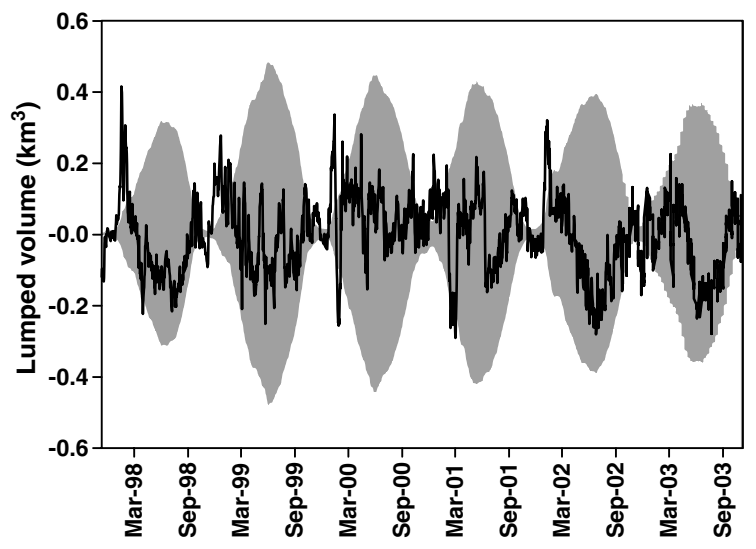

Figure 7 Difference between the computed and measured volume. Uncertainties on the measured volume are also reported (shadow area). A positive sign indicates a loss for the lake is required to obtain a better fit.

at each time step. Depending on the water year, it ranges between $84 \pm 7$ days and $97 \pm 11$ days with a mean value of $90 \pm 6$ days for the whole study period.

\section{Comparison with other floodplains in the Amazonian basin}

Due, in part, to the difficulty of collecting the necessary data, hydrologic characteristics of floodplain lakes have been studied in few tropical or Amazon basin sites. Among these studies, the closest to our site is Lake Calado $\left(3^{\circ} 15 \mathrm{~S}, 60^{\circ} 34^{\prime} \mathrm{W}\right)$, located in the central Amazon basin, and intensively studied by Lesack $(1993,1995)$, Lesack and Melack (1995). This floodplain lake is connected to the Solimões River year-round; the portion of the lake that always contained water is about $2 \mathrm{~km}^{2}$, the maximum flooded area is about $8 \mathrm{~km}^{2}$. The lake's local catchment has an area of $58 \mathrm{~km}^{2}$ and was covered by evergreen forest with some conversion to agriculture at the time of Lesack's study. Lake Calado and its catchment are smaller and have a simpler linkage to the mainstem than the floodplain of Lago Grande de Curuaí. The one full water year studied at L. Calado had rainfall of $2590 \mathrm{~mm}$. Runoff from the local catchment was determined by measuring discharge with a weir on one stream, rainfall at several sites and extrapolation to the entire basin and was estimated to be $1470 \mathrm{~mm}$. Rainfall onto the surface of the lake accounted for $11 \%$ of the input of water in the case of Lake Calado, which is comparable with the value found for the Curuaí floodplain. Runoff accounted for $57 \%$ the total water input for L. Calado while at Lago Grande de Curuaí, runoff contributed about $20 \%$ by the end of each year. This is explained by the ratio between the lake's local catchment and the maximal flooded surface which is about 7.5 for Lake Calado and only 1.6 for the floodplain of Lago Grande de Curuaí.

In the case of Lake Calado, river inflow accounted only for $21 \%$ of the lake water mixture and export into the river was about 3.3 times higher. In the case of the floodplain of Curuaí, by the end of each water year, the river water 
accounted for about $80 \%$ for 2000-2001 and 2001-2002 water years. The ratio between inflows and outflows ranged between 1.1 and 1.3 and is less than the ratio found for Lake Calado. This can be explained by the different ways the lakes are connected to the river. In the case of the Lake Calado, a single channel is the primary link of the lake to the Solimões River. In contrast, the Curuaí floodplain is connected to the Amazon River by several channels. Fluxes in the upstream channels Al10-Al70 are only inflowing, while fluxes in the downstream channel Al80 may be in the inflowing direction, but are more often in the outflowing direction. As observed for Lake Calado, we found that during the rising period, rainfall onto the surface of the lake and local runoff prevent river water from entering the lake, at least in the downstream channel, in which small changes in the rates of rise of the river or floodplain determine the flow direction.

Based on direct measurements, Lesack and Melack (1995) estimated that seepage from the groundwater system (bank storage) accounted for about $4 \times 10^{6} \mathrm{~m}^{3}$ (about $7 \%$ of the maximal volume reached during the water year) and that the volume of water that seeped out of the lake during the rising water period was about 1.5 times the volume of water received from groundwater during the falling water period. In the case of the Curuaí floodplain, the computed contribution from the groundwater system was estimated to about $9 \%$ of the maximal volume reached each year and is about 4 times the volume of water that seeped out of the lake. However, the ratio between seepage from and into the groundwater system is highly variable among water years.

\section{Conclusions}

This study presents an analysis of the temporal dynamics of the lake water mixture and fluxes between the river and a floodplain located along the lower Amazon River. The main results are as follows:

Each year, the storage stage of the floodplain starts between November and January and lasts until May-June. The draining phase starts in July and lasts until November; the largest exported volume occurs from August until October. On an annual basis, the floodplain represented a source of water to the Amazon River.

Water from the Amazon River and from runoff from watershed located in the ATTZ and local upland catchments are the two main sources of water. Depending on the hydrologic characteristics of the water year, the Amazon River constituted between $70 \%$ and $90 \%$ of the water inputs. Seepage from the ground water system contributed to less than $5 \%$. Significant inter-annual variations are evident.

The river water residence time within the floodplain is 5 months \pm 0.8 month while the residence time of water from all sources is $3 \pm 0.2$ months.

\section{Acknowledgements}

This research was funded by the joint CNPq (Conselho Nacional de Desenvolvimento e Pesquisa Tecnologica, Brazil) IRD (Institut de Recherche pour le Développement, France)
Project HIBAm (Hydrology and Geochemistry of the Amazon Basin) and by the French National Research Council (CNRS, programs ECCO, PNRH and PNBC). It uses data acquired in the framework of the ORE Hybam (IRD, INSU). The authors would like to thank the technical groups of Agencia Nacional das Aguas from Brazil (ANA) and Companhia de Pesquisa dos Recursos Minerais (CPRM, Manaus) for furnishing part of the data used in the study and for their help during the cruises.

\section{References}

Alsdorf, D.E., Melack, J.M., Dunne, T., Mertes, L.A.K., Hess, L.L., Smith, L.C., 2000. Interferometric radar measurements of water level change: Amazon floodplain response to river stage. Nature 404, 174-177.

Barroux, G., Viers, J., Seyler, P., Oliva, P., Dupré, B., Guyot, J.L., Pinelli, M., 2003. How plants of the Amazon floodplain (Brazil) can affect the geochemical status of trace elements in the Amazon River mainstream? J. Phys. IV 107, 119-125.

Birkett, C.M., Mertes, L.A.K., Dunne, T., Costa, M.H., Jasinski, M. 2002. Surface water dynamics in the Amazon Basin: application of satellite radar altimetry. J. Geophys. Res. 107 (D20), LBA 261-LBA24-21.

Bonnet, M.P., Barroux, G., Seyler, P., Pecly, G., Moreira-Turcq, P., Lagane, C., Cochonneau, G., Viers, J., Seyler, F., Guyot, J.L., 2005. Seasonal links between the Amazon corridor and its floodplain - the case of the varzea of Curuai. In: IAHS (ed.), IAHS. IAHS Publication 294, Foz de Iguacu, Brazil, pp. 69-77.

Bonnet, M.P., Poulin, M., Devaux, J., 2000. Numerical modeling of the thermal stratification in a lake reservoir: methodology and case study. Aquatic Sci. 62, 105-124.

Callède, J., Guyot, J.L., Ronchail, J., Molinier, M., de Oliveira, E., 2002. L'Amazone à Óbidos (Brésil): étude statistique des débits et bilan hydrologique. Hydrol. Sci. - J. des Sciences Hydrologiques 47 (2), 321-333.

Callède, J., Kosuth, P., Guyot, J.L., Guimarães, V., 2000. Discharge determination by accoustic doppler current profiler (ADCP). Hydrol. Sci. J. 45 (6), 911-924.

Callède, J., Kosuth, P., Oliveira, E., 2001. Etablissement de la relation hauteur-débit de l'Amazone à Óbidos: méthode de la dénivelée normale à géométrie variable. Hydrol. Sci. J. 46 (3), 451-463.

Cauhope, M., 2004. Hauteur d'eau d'une plaine d'inondation amazonienne par altimétrie spatiale. DEA Thesis, Université Paul Sabatier, Toulouse, pp. 30.

Dunne, T., Mertes, L.A.K., Meade, R.H., Richey, J.E., Forsberg, B.R., 1998. Exchanges of sediment between the flood plain and channel of the Amazon River in Brazil. Geol. Soc. Am. Bull. 110 (4), 450-467.

Filizola, N., Guyot, J.L., 2004. The use of Doppler technology for suspended sediment discharge determinations in the River Amazon. Hydrol. Sci. J. 49 (1), 143-153.

Guyot, J.L., Filizola, N., Laraque, A., 2005. Régime et bilan du flux sédimentaire de l'Amazone à Óbidos (Pará, Brésil), de 1995 à 2003. Sediment budgets, IAHS Publ., pp. 347-356.

Hamilton, S.K., Sippel, S.J., Melack, J.M., 2002. Comparison of inundation patterns among major South American floodplains. J. Geophys. Res. 107 (D20), LBA-1-LBA1-4.

Hess, L.L., Melack, J.M., Novo, E.M.M., Barbosa, C.C.F., Gastil, M., 2003. Dual season mapping of wetland inundation and vegetation for the central Amazon basin. Remote Sensing Environ. 87, 404428.

Jaccon, G., 1987. Jaugeage de l'Amazone à Obidos par les méthodes du bateau mobile et des grands fleuves. Hydrol. Continent. 2 (2), 117-126. 
Junk, W.J., 1997. General aspects of floodplain ecology with special reference to Amazonian floodplains. In: Junk, W.J. (Ed.), The Central-Amazonian Floodplain: Ecology of a Pulsing System, Ecological Studies. Springer Verlag/Heidelberg, Berlin/New York, pp. 3-22.

Lesack, L.F.W., 1993. Water balance and hydrologic characteristics of a rainforest catchment in the central Amazon basin. Water Resour. Res. 29, 759-773.

Lesack, L.F.W., 1995. Seepage exchange through the lakebed in an Amazon floodplain lake. Limnol. Oceanogr. 40, 598-609.

Lesack, L.F.W., Melack, J.M., 1995. Flooding hydrology and mixture dynamics of lake water derived from multiple sources in an Amazon floodplain lake. Water Resour. Res. 31 (2), 329-345.

Martinez, J.M., Le Toan, T., 2007. Mapping of flood dynamics and vegetation spatial distribution in the Amazon flooplain using multitemporal SAR data. Remote Sensing Environ. 108 (3), 209233.

Maurice-Bourgoin, L., Martinez, J.M., grelaud, J., Boaventura, G.R., Filizola, N., 2005. The role of floodplain in the hydrology and sediment dynamics of the Amazon River. In: I. Publication (Ed.), IAHS. IAHS Publication 291, Foz do Iguaço, Brazil.

Meade, R.H., Dunne, T., Richey, J.E., Santos, U.M., Salati, E., 1985. Storage and remobilization of suspended sediment in the lower Amazon river of Brazil. Science 228, 488-490.

Melack, J.M., Forsberg, B.R., 2001. Biogeochemistry of Amazon floodplain lakes and associated wetlands. In: McClain, M.E., Victoria, R.L., Richey, J.E. (Eds.), The Biogeochemistry of the Amazon Basin and its Role in a Changing World. Oxford University Press, Oxford, pp. 235-276.

Melack, J.M., Hess, L.L., Gastil, M., Forsberg, B.R., Hamilton, S.K., Lima, I.B.T., Novo, E.M.L.M., 2004. Regionalization of methane emissions in the Amazon basin with microwave remote sensing. Global Change Biol. 10, 530-544.

Mertes, L.A.K., Daniel, D.L., Melack, J.M., Nelson, B., Martinelli, A., Forsberg, B.R., 1995. Spatial patterns of hydrology, geomorphology, and vegetation on the floodplain of the Amazon River in Brazil from a remote sensing perspective. Geomorphology 13, 215-232.

Moreira-Turcq, P., Jouanneau, J.M., Turcq, B., Seyler, P., Weber, O., Guyot, J.L., 2004. Carbon sedimentation at lago grande de Curuai, a floodplain lake in the low Amazon region; insights into sedimentation rates. Palaeogeogr. Palaeoclimatol. Palaeoecol. 214, 27-40.

Moreira-Turcq, P., Barroux, G., Bernades, M., Bonnet, M.P., Maurice-Bourgoin, L., Perez, M., Seyler, P., 2005. Dynamics of organic carbon between Amazon river and floodplain lakes. In: IAHS (Editor), IHAS. IAHS Publication 294, Foz de Iguaçu, Brazil, pp. 19-26.

Rabus, B., Eineder, M., Roth, A., Bamler, R., 2003. The Shuttle Radar Topography Mission - a new class of digital elevation models acquired by spaceborne radar. Photogrammetry Remote Sensing 57, 241-262.

Richey, J.E., Devol, A.H., Wofsy, S.C., Victoria, R., Ribeiro, M.N.G., 1988. Biogenic gases and the oxidation and reduction of carbon in Amazon River and floodplain waters. Limnol. Oceanogr. 33 (4), 551-561.

Richey, J.E., Hedges, J.I., Devol, A.H., Quay, P.D., Victoria, R., Martinelli, L., Forsberg, B.R., 1990. Biochemistry of carbon in the Amazon river. Limnol. Oceanogr. 35 (2), 352-371.

Richey, J.E., Mertes, L.A.K., Dunne, T., Victoria, R., Forsberg, B.R., Tancredi, A.C.F.N.S., Oliveira, E., 1989. Source and routing of the Amazon River flood wave. Global Biogeochem. Cycles 3 (3), 191-204.

Riou, C., 1975. La détermination pratique de l'évaporation. Application à l'Afrique Centrale. 80, ORSTOM.

Seyler, P., Boaventura, G.R., 2001. Trace elements in the mainstream Amazon River. In: McClain, M.E. (Ed.), The Biochemistry of the Amazon Basin. Oxford University Press, Oxford, UK, p. 534.

Seyler, P., Boaventura, G.R., 2003. Distribution and partition of trace metals in the Amazon basin. Hydrol. Process. 17, 13451361.

Sippel, S.J., Hamilton, S.K., Melack, J.M., 1992. Inundation area and morphometry of lakes on the Amazon River floodplain, Brazil. Arch. Hydrobiol. 123, 385-400.

Sippel, S.J., Hamilton, S.K., Melack, J.M., Novo, E.M.M., 1998. Passive microwave observations of inundation area and the area/stage relation in the Amazon River floodplain. Int. J. Remote Sensing 19 (16), 3055-3074.

UACE, 2003. Geospatial hydrologic modeling extension HECGeoHMS, User Manual, US Army Corps of Engineers, Davis, CA 95616. 